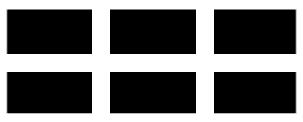

ThE WILliam DAVIDSON INSTITUTE AT THE UNIVERSITY OF MICHIGAN BUSINESS SCHOOL

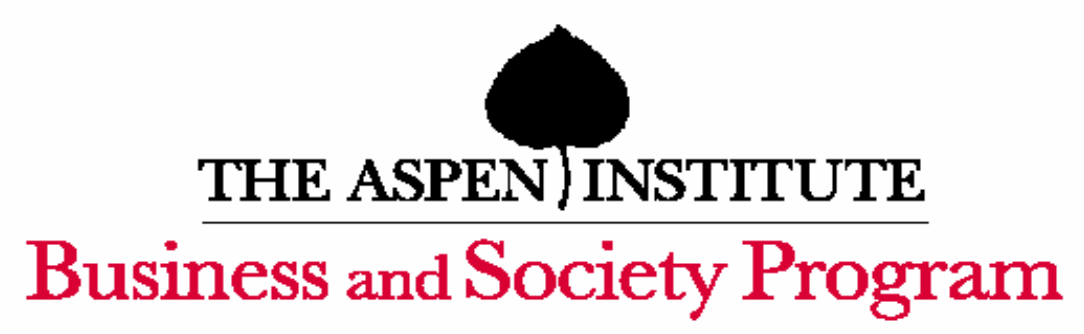

\title{
Globalization and Trust:
} Theory and Evidence from Cooperatives

\author{
By: Ramon Casadesus-Masanell Tarun Khanna
}

William Davidson Institute Working Paper Number 592 June 2003 


\title{
Globalization and Trust: Theory and Evidence from Cooperatives"
}

\author{
Ramon Casadesus-Masanell Tarun Khanna ${ }^{\dagger}$
}

March 9, 2003

Preliminary

\begin{abstract}
We study the effect of globalization on the stock of trust in organizations. We present a simple model of endogenous trust and show that contrary to centralized hierarchies (pure limited liability firms), decentralized organizational structures (cooperatives) foster the emergence of trust. We treat organizations as directly observable 'summary statistics' for underlying trust and ask what will be the fate of trust as the world becomes increasingly globalized. Because the cooperative is an intrinsically less efficient organizational form and globalization implies harsher competitive pressures, conventional wisdom suggests that the viability of cooperatives is in jeopardy. We show that this is not necessarily true. If the increase in competition is bundled with an increase in uncertainty and risk, the cooperative may become a more efficient organizational form. We conclude that globalization does not necessarily erode trust. The case of Mondragón Corporación Cooperativa is used to motivate assumptions and illustrate the results.
\end{abstract}

\footnotetext{
*We thank seminar participants at "Trust, Institutions and Globalization" held in Ann Arbor, MI (November 2002) and Harvard Business School.

${ }^{\dagger}$ Harvard Business School.
} 


\section{Introduction}

We ask whether globalization erodes trust, as has been commonly asserted by scholars and in the popular media. We do this by building a model in which trust emerges endogenously among interacting individuals. Different organizational forms represent different levels of underlying trust. We then ask how globalization - modeled as a set of empirically defensible parameters - affects the emergence of trust and, therefore, the incidence of different kinds of organizations. Thus, we depart from the now common approach of surveying individuals about their espoused levels of trust and subjecting their responses to analyses under various treatment effects. We resort instead to treating different organizations as directly observable 'summary statistics' for underlying trust. While our approach has limitations, it is at least free from the biases that might accompany surveys of trust.

Our model first predicts, simply, that there are higher levels of trust, and greater wage equality, in cooperatives (organizations wherein employees own the firm) than in limited liability firms, and that cooperatives are more likely to form in situations where there is ex ante wealth equality. We document this to be true in the case of one organization, the $\$ 8$ billion Mondragon Cooperaction Cooperativa (MCC), in the Basque country - a conglomeration of cooperatives. Within MCC, we show that the cooperative with the greatest degree of wage equality, Irizar, is one of the most globally successful.

More counter-intuitively, we demonstrate that, while cooperatives are intrinsically less efficient than limited liability firms, they may nonetheless thrive as globalization intensifies. This is quite in contrast to existing theories which predict that increased competition (Hart and Moore, 1998; Miyazaki, 1984) and times of uncertainty (Hart \& Moore, 1998) - both of which are characteristic features of globalization - will weaken cooperatives. Admittedly, globalization is a complex phenomenon; we do it some violence by treating it in a rather spare way - as a conjunction of an expansion in market size, an increase in price competition (to represent increased competitive intensity), and an increase in the variance of performance (conditional on a given level of factor inputs). The increased risk, in particular, is instrumental in ensuring the continued viability indeed even the thriving - of cooperatives despite the lower level of profitability of this organizational form relative to a limited liability company. Returning to the case study, we show that Irizar's improvement in performance has occurred contemporaneously with greater exposure to global competitive forces. Further, this is the time during which greater wage equality has become institutionalized. While alternative explanations can be posited - and we consider these at length - our field interviews lend greatest credence to the act of cooperation being central to sustaining Irizar's performance in the face of global competition. Thus, our model is consistent with the experience of one of the world's most extensively studied cooperatives (Bonin, et al. 1993; Miyazaki, 1984) and contrary to the predictions of extant models of cooperatives.

Our theorizing and case study empirics lead us to the following contributions. First, contrary to the conventional wisdom, we do not subscribe to the view that globalization necessarily erodes trust, at least not trust as manifested in workplace settings. Second, 
scholarly views regarding the (lack of) resilience of organizational form in the face of intensified competition should be revisited. Increased competition, in our setting, comes bundled with greater instability - while one part of this bundled phenomenon (called globalization) indeed erodes the viability of cooperatives and the trust they represent, another augments it.

\section{Literature review}

This section delineates how our modeling of each of 'trust' and 'globalization' relate to popular and scholarly conceptions in the extant literature. We then discuss the rather sparse literature on the effect of globalization on organizational structure.

Consider, first, common definitions of trust. The dictionary defines trust as "a confident reliance on the integrity, veracity, or justice of another." Gambetta (1988) claims: "when we say we trust someone or that someone is trustworthy, we implicitly mean that the probability that he will perform an action that is beneficial or at least not detrimental to us is high enough for us to consider engaging in some form of cooperation with him." To Fukuyama (1995), "trust is the expectation that arises within a community of regular, honest, and cooperative behavior, based on commonly shared norms, on the part of other members of that community."

Scholars have diverged in how they treat trust. Economists adopt a standard gametheoretic conception of trust, essentially asserting that trust can be sustained as equilibrium behavior in repeated games. ${ }^{1}$ Sociologists suggest that this notion of trust is at odds with the intuition that individuals sometimes act in a trustworthy way even in an end-game situation. Thus, Granovetter (1999) define trust as "the confidence that another will not take advantage of you despite clear incentives to do so, even in 'end-game'." Our theoretical treatment of trust builds instead on Casadesus-Masanell's (2000) economic treatment of emotions such as guilt, shame, or altruism - emotions which underlie the sociologist objection to the standard economists' repeated game treatment of trust. This model has trust building on the preference structure of individual actors in a principal-agent setting, not in response to external inducements. Thus, we adopt a theoretical treatment that bridges conceptions of economists and sociologists.

Others have concentrated on examining the effects of trust, rather than its antecedents, drawing inspiration from Arrow's contention that "[v]irtually every commercial transaction has within itself an element of trust, certainly any transaction conducted over a period of time. It can plausibly be argued that much of the economic backwardness in the world can be explained by the lack of mutual confidence." Consistent with this contention, Sapienza and Zingales (2002) measure the incidence of trust by the aggregate use of financial instruments in a population (checks, deposits, etc. as opposed to cashunder-a-mattress). But by far the most popular measure of trust is based on surveys such as the World Values Survey (LLSV Aer paper, Fisman and Khanna). In contrast to this

\footnotetext{
${ }^{1}$ See also Casadesus-Masanell and Spulber (2002).
} 
burgeoning line of work, we rely on our theorizing regarding the endogenous emergence of trust to treat organizations as summary statistics for the extent to which the constituent individuals trust each other, and treat the directly observable and measurable changes in the organization as the signature of changing underlying trust levels.

There is a considerable literature on cooperatives - see, for example, Ward's (1958) seminal paper, Hansmann's (1996) comprehensive treatment and Bonin et al. (1993)'s survey article. While intuitively cooperatives are thought of as associated with a greater degree of trust, solidarity and mutual self-reliance than are limited liability firms, there are no explicit treatments of trust in cooperatives of which we are aware. Here we confine ourselves to mentioning two theoretical approaches because they illustrate alternative means to some commonly held theoretical priors about cooperatives, which our model and case study will end up disputing. The first of these is Miyazaki's (1984) model of the evolution of labor-managed enterprises. His argument is that limited liability firms morph into cooperatives in times of trouble - think of employee buyouts of troubled firms. The intuition is that, because employees care about job security (whereas outside investors do not), an employee owned firm may be content with lower wages (and explicit attention to job security) than an outside-investor owned firm (that does not care about job security). The lower wages might make the firm viable in times of distress. The implication is that cooperatives will underperform limited liability firms, though it is important to note that the poor performance causes the cooperative to exist, rather than the act of cooperation inducing inefficiency. This model fundamentally articulates a 'selection story' - when do workers self-select into cooperatives. We will argue later that this model's implications are not borne out in our case analytics, nor is there evidence of this selection process operating in our case.

A model with a very different engine but with implications for our case study is the more recent effort by Hart and Moore (1998). They compare an outsider-owned (conventional) firm with a cooperative (owned by consumers). They find different sources of inefficiency relative to first-best in each organizational type. The outsider-owned firms underproduces, i.e. there are consumers who have a willingness-to-pay in excess of marginal cost who do not consume. The cooperative overproduces - the rents in earns are used to subsidize overconsumption by cooperative members (at the expense of non cooperative members who might value the good higher). Since the rents used in this inefficient subsidization reduce in the face of greater competition, an implication is that cooperatives are less likely to exist as competition ratchets up. Hart and Moore also find that cooperatives make more efficient choices when the preferences of their members are closely aligned, and thus suggest that cooperatives are a particularly bad structure in times of flux. We will argue, in contrast to this effort, that Mondragon did especially well and expanded precisely in times of flux and in times of ratcheting intensity of competition.

Next, consider the massive literature on globalization. One relevant strand is historical where the focus is on understanding the extent and nature of movements of finished goods and services and factors of production across borders through (typically) the last two centuries (O'Rourke and Williamson; Taylor and Obstfeld). Numerous changes in industrial organization are attributed to the effects of various forms of (increases and 
decreases in) globalization. However, others have sometimes contested the importance of the effects of such cross-border commerce, relative to intra-country changes, particularly technological changes (Feenstra) and political changes (Fairbank on China). For our purposes, the main point is to note that this massive literature does not generally talk about firms or their organizations; instead much of the theoretical and empirical analysis is at the level of the industry or the level of the individual economic agent.

Another relevant strand - tangentially related to the existence of trust and trusting societies - has to do with the effects of globalization on the social fabric. Rodrik offers an economic treatment of this issue suggesting that some form of redistribution will ultimately be needed to compensate 'losers' from the rent-reallocation that results from globalization, in order to 'buy' their support for the process (in an implicitly at least partly democratic society). Chua's recent book provides colorful, and distressing, anecdotal evidence of the distress caused by global forces in individual societies. The media itself is full of statements regarding the distress caused by the destabilizing effects of globalization (with much of the focus being on destabilizing capital flows - so-called 'hot money'). Malaysia, under Mahathir Mohamad, is the poster-child of resistance to globalization, often citing that as a multi-ethnic society in (some would say) precarious equilibrium, it cannot afford being destabilized by unchecked global commerce.

But there is surprising inattention to the effect of global commerce on firms or on organizational structure, despite the increasing acceptance of the greater exposure to globalization engineered by (or forced upon) numerous countries (Sachs and Warner, 1995). Recently Marin and Verdier (2002) offer a model wherein flatter corporate hierarchies and empowerment of human capital are related to increased cross-border trade. But prior to this, Ghemawat and Khanna (1998) and Khanna and Palepu (1999) respectively modeled and empirically analyzed the effect of a country's opening up to global commerce on business groups - diversified family-run organizations that often form the backbone of the private sector of most economies. They find that mere 'liberalization,' often equated with dismantling of regulatory red-tape, is insufficient to foster competition and force change in corporate structures. As a corollary, one might conclude that such changes in corporate structure as predicted by Marin and Verdier (2002), for example, probably typically lag by several years - the previous studies suggest a non-trivial time period of the order of a decade - the initiation of a process of opening up to global commerce.

The spirit of these findings was that organizations might not respond to common proxies of increased competition, because the proxies are inaccurate. De jure liberalization and opening up to competition is not synonymous with de facto competition, because a variety of other institutional arrangements have to come into place before competitive forces can operate. In contrast, here we argue that globalization is a 'bundled phenomenon' - it rarely comes just as a ratcheting up of competition. It typically also includes increases in risk and instability. The crux of our model and case empirics is to suggest that the ratcheting of competition and increased instability often have offsetting effects on organizational structure and on underlying interpersonal trust. Indeed, in our model, there are plausible circumstances when the instability effect dominates, so that 
trust, and the kind of intra-organizational coordination that it fosters, rise with globalization. This is interesting precisely because it runs counter to the groundswell of literture suggesting the converse. Nor is this strictly a theoretical conjecture. Our case analysis will show this, but prior cases have also shown analogous findings. Indian and Chilean business groups tightened intra-group corporate bonds and intra-group family ties in response to increased globalization, and did so profitably (Khanna and Palepu).

There is one other circumstance when globalization and cooperative formation co-occur. Our impression is that several employee-owned and managed cooperatives were created in the transition economies in Central and Eastern Europe following the fall of communism. One can interpret the opening up of these economies as greater exposure to global forces. But the formation of cooperatives in this instance is not in response to globalization (at least not to the greater incidence of competition which we model) rather it appears to be at least partly a means by which capital-constrained individuals can begin to come together to engage in productive enterprise in situations with poor external capital markets.

Finally, note that our paper considers the effects of (some aspects of) globalization on trust. The reverse causality - with which we are not concerned - could also obtain, i.e. trust could lead to globalization. This is the engine behind Greif's theorizing about crossborder ethnic networks in medieval times. It is also the aspect emphasized by recent attention to diaspora networks (Kotkin, Rauch and Trinidade).

\section{The Model}

The basic set up is as in Holmstrom (1982). In the simplest specification there are two workers, $i=1,2$. Workers exert effort $a_{i}$. Output given by $y=f\left(a_{1}, a_{2}\right)$, a deterministic function of effort levels. We assume that $f$ is differentiable and that $f_{i}>0$ and $f_{i j}>0$

so that more effort implies more output and efforts are strategic complements. There is an opportunity cost of effort $c\left(a_{i}\right)$ that we assume increasing and convex. Assume for simplicity that $y=a_{1}+a_{2}+k a_{1} a_{2}$ and $c\left(a_{i}\right)=c a_{i}^{2}$ with $c>k>0$.

It is easy to compute the first best level of effort. This is the level of effort that would optimally be required from each worker if effort was observable. The first best effort $\left(a_{1}^{* *}, a_{2}^{* *}\right)$ solves

$$
\max y-2 c\left(a_{i}\right)
$$

The first order conditions characterizing the first best efforts are $f_{i}=c^{\prime}\left(a_{i}\right), i=1,2$. We use $y^{* *}$ to denote the first best output. 
Throughout the paper we assume that effort is non-observable. If effort was observable, organizational form would be of no consequence as contracts could be used to achieve any outcome. Because effort is non-observable, contracts can only be written on total output $y$. Let $\left(\alpha_{1}, \alpha_{2}\right)$ be a sharing rule: $\alpha_{i} y$ is the payment to worker $i$. Of course, $\alpha_{1}+\alpha_{2} \leq 1$.

Holmstrom shows that there is free riding for all possible sharing rules: each worker considers his own full cost of effort but only a portion $\alpha_{i}<1$ of benefits. The 'free rider' efforts $\left(\hat{a}_{1}, \hat{a}_{2}\right)$ are obtained by solving

$$
\max _{a_{i}} \alpha_{i} y-c\left(a_{i}\right)
$$

The first order conditions are $\alpha_{i} f_{i}=c^{\prime}\left(a_{i}\right), i=1,2$. Therefore, $\hat{a}_{i}<a_{i}^{* *}$. Let $\hat{y}$ denote the free-rider output.

\subsection{Social Preferences}

We depart from standard economic theory in that we allow the workers to develop emotions that may result in trustworthy behavior. We distinguish between material payoffs (the true utility function, or the object self) and behavior payoffs (the utility function used in acting, or the acting self). Viewing the self as an entity of parts with some components making use of others is common in sociology, psychology, and social psychology. ${ }^{2}$ In The Theory of Moral Sentiments in 1759, Adam Smith distinguished between the object self, the acting self, and the "judge," who evaluates the agent's and others' actions. This notion also has been used in economics by Akerlof (1970), Frank (1987), Raub (1990), Rabin (1993), and Rotemberg (1994), among others.

Material payoffs refers to the standard preferences: unsocialized, effort-averse, and selfish. While the agent's material payoffs are taken as given, behavior payoffs are endogenously generated within the model. Workers play the following two-stage game. In stage 1, the workers mold their behavior payoffs to serve best their object self. That is, the workers use their selfish utility function to evaluate the desirability of social norms or ethical standards. In the case of norms the agents choose whether to feel pressure to abide by norms and with ethical standards, they choose whether to develop pressure to abide by the standard. We assume that once the agents have chosen their behavior payoffs, they are bound to act according to them. In other words, they credibly commit to observable pressure. Credibility requires that it be difficult for an agent who is bound by norms or ethical standards to imitate the signals that those truly experiencing these emotions display. $^{3}$

\footnotetext{
${ }^{2}$ See Coleman (1990) for extensive references.

${ }^{3}$ For example, Frank (1987) points out that "[a] strategically important emotion can be communicated credibly only if it is accompanied by a signal that is at least partially insulated from direct control. Many observable physical symptoms of emotional arousal satisfy this requirement. Posture, the rate of
} 
In stage 2, a standard partnership game unfolds. If there is a principal, he offers a contract and each worker decides how much effort to exert. If there is no principal, the workers decide on effort taking into account the portion of output that they have agreed to. After output is realized, the corresponding transfer takes place.

Rotemberg distinguishes a number of interpretations for the first stage of this game. First, a selfish inner self relinquishes control of actions to the outer self. The inner self can mold the preferences that guide the outer self's choices. The inner self can make the outer self altruistic, bound by ethical standards or norms. Such feelings become genuine because the inner self can only change the outer self's preferences slowly. Second, if emotional reactions are guided by genes, natural selection might favor the reproduction of individuals whose emotions change in a self-interested way. Finally, natural selection favors those genes that lead people to imitate the behavior of individuals that appear successful. If people appear successful when their material payoffs are high and the parameter values of successful individuals can be inferred from their behavior, then people will be led to choose parameters in a way that maximizes expected material payoffs.

\subsubsection{Trust}

The free-rider problem in the benchmark model is due to moral hazard. Moral hazard is unavoidable when effort cannot be perfectly monitored. Larger output and utility levels would be achieved if the agents were ready to honor agreements that asked for larger effort. Because the workers shirk when guided by their material payoffs (unless appropriate extrinsic incentives are granted), we refer to their material payoffs as untrustworthy preferences. Therefore, we use the standard partnership framework as the no-trust benchmark. We begin by defining trustworthiness.

Definition $A$ worker is trustworthy if he is expected to exert more effort than what material preferences would induce (given an incentives schedule).

Trustworthiness is a matter of degree. It is interesting to relate our definition of trust with the sociology view on trust. According to Mark Granovetter (1999), "the most common definition of 'trust' is precisely the confidence that another will not take advantage of you despite clear incentives to do so, even in 'end-game'." In the present context, the "confidence that another will not take advantage of you" is captured in that when agent 1 trusts agent 2 not to free-ride, if agent 2 ends up maximizing his material payoffs, then agent 1 is worse off than if he had not trusted agent 2. "[D] espite clear incentives to do so" is captured in that the object self has always an incentive to breach trust. Finally, "even in 'end-game'," is reflected in that the model is static and compliance cannot rely

respiration, the pitch and timber of the voice, perspiration, facial muscle tone and expression, movement of the eyes, and a host of other readily observable physical symptoms vary systematically with a person's affective condition." 
on self-enforcement of the type considered in the repeated games literature. We can now define trust:

Definition Agent $i$ trusts agent $j$ if agent $i$ chooses a best response to the effort that agent $j$ would take if he was trustworthy.

Notice that trust is defined as behavior and not as the cause of behavior. In other words, trust is the taking of an action that best responds to the action of a trustworthy co-worker. We do not say that such action is taken by agent $i$ because trusts agent $j .{ }^{4}$

\subsection{Organizational Alternatives}

Theoretically, we consider two extreme organizational forms, the pure hierarchy (L) and the pure horizontal organization (C). In a pure hierarchy, a boss who is the owner of capital contracts with workers who get a wage in exchange for their work. The owner gets the residual profit after wages have been paid to the workers. In a pure horizontal organization there are no bosses and all workers share profit. The pure hierarchy will referred to as the (pure) 'limited liability' firm. Here we have in mind the old, traditional hierarchy where workers are not allowed to participate in decision-making and bosses have absolute power, as in Dickens's "Hard Times."

The pure horizontal organization will be referred to as the (pure) 'cooperative.' This is the socialist ideal where everyone contributes to the project and is willing to work without externally imposed punishments or rewards. An organization with few layers of authority where individuals are given the responsibility to work without direct monitoring. These organizations are also rare in pure form. The cooperative (or the Ilyrian firm) is a good example of the pure horizontal organization given that in its purest form all cooperators are owners and thus there are no bosses. ${ }^{5}$ One main extrinsic incentive to work in a cooperative comes from the cooperators' participation in the profits of the company.

\subsection{Horizontal Organization}

In a workers' cooperative the workers are owners. There are no bosses. As mentioned above, each cooperativist receives a portion $\alpha_{i}$ of output, with $\alpha_{1}+\alpha_{2}=1$. Since there are no bosses, each cooperativist decides how much effort to exert by maximizing his/her own utility.

\footnotetext{
${ }^{4}$ For a critique of Williamson's (1993) notion of calculative trust based on the grounds that he does not distinguish between trust as behavior and trust as cause of behavior, see Craswell (1993).

${ }^{5}$ We will refer to workers in cooperatives as 'cooperators.'
} 
We allow the members of the cooperative to develop psychological pressure to abide by social norms or standards of ethical behavior if they wish to do so. Thus, cooperativist $i$ 's social preferences are

$$
u_{i}=a_{i} y-c a_{i}^{2}-\lambda_{i}\left(\overline{\mathrm{v}_{i}}-\mathrm{v}_{i}\left(a_{i}\right)\right)
$$

where $\bar{v}$ is a social norm or ethical standard and $\lambda$ (which is a choice variable) is the pressure or not (depending on whether $\lambda>0$ or $\lambda \leq 0$ ) to abide by the norm or ethical standard. An example of an ethical standard is, ${\overline{\sigma_{i}}}_{i}=a_{i}^{* *}$ the first best level of effort and $v_{i}\left(a_{i}\right)=a_{i}$. This is an ethical standard because it is non-observable. Parameter $\lambda_{i}>0$ represents worker $i$ 's personal pressure to abide by the ethical standard. An example of a social norm is $\bar{v}=y^{* *}$ the first best level of output. In this case, $v_{i}\left(a_{i}\right)=f\left(a_{i}, a_{j}^{* *}\right)$. This is a social norm because output is assumed to be observable. In this case, $\lambda_{i}$ represents how much the agent cares about others observing the difference between the norm and $y$. In what follows we assume that $\bar{v}_{i}=a_{i}^{* *}$ the first best level of effort and $v_{i}\left(a_{i}\right)=a_{i}$. It is important to stress that $\lambda_{i}$ is chosen by the agent and thus it can be positive, negative, or zero.

In the first stage, the cooperativists shape their preferences by choosing $\left(\lambda_{1}, \lambda_{2}\right)$ simultaneously. The choice is made to maximizing the workers' material payoffs (unsocialized payoffs that do not include pressure to abide by social norms or standards of ethical behavior):

$$
u_{i}=\alpha_{i} y-c a_{i}^{2}
$$

In the second stage, the cooperativists choose effort $\left(a_{1}^{c}, a_{2}^{c}\right)$ simultaneously by maximizing their 'behavior' payoffs (2). These are socialized payoffs. It is easy to see that:

Proposition 3 Given $\alpha_{i}, a_{i}^{* *}>a_{i}^{c}>\hat{a}_{i}$ and $\lambda_{i}>0$

The cooperativists develop pressure to abide by social norms or ethical standards. The reason is that efforts are strategic complements and thus forcing oneself to work a little harder also induces the other cooperativist to work harder. ${ }^{6}$

In equilibirum there is some free-riding but less than in the standard model where workers are not allowed to develop internal pressure to abide by social norms or standards of ethical behavior. The pressure to abide by the standard results in 'intrinsic' incentives to work. Extrinsic incentives (the commission rate) increase the material

\footnotetext{
${ }^{6}$ In fact, $\lambda_{i}<0$ when efforts are strategic substitutes. But in this case, there is no reason to set up the organization because $f\left(a_{1}, a_{2}\right)<f\left(a_{1}, 0\right)+f\left(0, a_{2}\right)$.
} 
wealth of the worker. Intrinsic incentives are 'built in' the preferences. When $\lambda_{i}>0$ failure to perform up to the social norm or personal standard results in feelings of shame or guilt, respectively. Notice finally that overachieving (in the sense of working harder than the social norm or standard of ethical behavior) results of feelings such as pride and or self-esteem.

\subsubsection{Trust}

We interpret the reduction of free-riding due to social norms or ethical standards as trustworthiness. Cooperativists trust each other to choose $a_{i}^{c}>\hat{a}_{i}$ because they know that social norms and standards of ethical behavior are at play. Thus,

Proposition 4 The cooperative fosters trust.

Below we present the case study of Irizar, a cooperative with a flat organizational structure, that displays high trust levels.

\subsubsection{Wage Equality}

If we add one more stage and let the cooperativists choose the sharing rule $\left(\alpha_{1}, \alpha_{2}\right)$ through negotiation (with equal negotiating power), the workers choose $\alpha_{1}=\alpha_{2}=\frac{1}{2}$. Thus,

Proposition 5 The cooperative promotes wage equality.

It is interesting to note that not only wage equality maximizes output but that it also maximizes trust. We now turn to the limited liability firm.

\subsection{Hierarchy}

In the limited liability model, there is an owner-boss and two workers. The owner has sufficient capital to set up the firm. The workers exert effort $a_{i}^{L}$ and the boss designs an incentives scheme. The boss keeps the residual product after the workers have been compensated for their effort.

The best contract the owner can offer is as follows. Workers get wage $w(y)=c_{i}\left(a^{* *}\right)$ as long as $y=y^{* *}$, otherwise $w(y)=0$. This ensures that workers choose $a^{L}=a^{* *}$. The boss makes more money than the cooperativists in the previous section. Thus, the capitalist is better off setting up a limited liability firm than a cooperative. However, workers' utility is lower in a limited liability firm. 


\subsubsection{Trust}

Just as in the cooperative model, we let the workers develop pressure to abide by standards of ethical behavior or social norms. In the case of the limited liability firm, however, the workers have no incentive to develop pressure to abide by standards of ethical behavior or social norms. The reason is that if they choose $\lambda>0$, then

$$
w=c(a)+\lambda(\bar{v}-v(a))
$$

at $a=a^{* *}$. But this is $w=c\left(a^{* *}\right)$ which is independent of $\lambda$. Thus, the first stage maximization involves no $\lambda$. Pressure cannot affect the willingness of the other party to work harder and each worker has no incentive to become trustworthy.

Proposition 6 The limited liability company discourages trust.

\subsubsection{Wage Equality}

Wages in the limited liability firm are unequal. The owner-boss gets $y^{* *}-2 c\left(a^{* *}\right)>0$ whereas the workers get $w=c\left(a^{* *}\right)$ which is just sufficient money to compensate for their effort. Clearly, the workers would be better off by setting up a cooperative (if they had the assets) because in a cooperative they would get strictly positive utility. Further wage inequality would be introduced if there were differences of ability.

\subsection{The Emergence of Cooperatives}

An important question that needs to be addressed at this point is: given that cooperatives are less efficient than limited liability firms, why do they exist? There are two parts to the question: first, what are the incentives to set up cooperatives? And second, will cooperatives survive in competition with limited liability firms?

The model suggests a way to answer the question. Suppose an individual with wealth that is insufficient to set up a firm. He has three options. First, he can team up with another individual who has some capital and set up a cooperative. He would then be a cooperativist and, according to the model, would achieve positive utility. Second, he could decide not to use his wealth and join a limited liability firm and work for a wage. The model suggests that this is not attractive as he will be paid the opportunity cost of labor only. Third, he can team up with someone else and set up a limited liability firm. This results in higher payoff than setting up a cooperative. But this is only possible if there are individuals willing to join the limited liability firm as wage workers. In the absence of such individuals, cooperatives will be formed in all likelihood. Thus, in social groups with income equally spread, we should expect cooperatives to thrive. In settings with wage inequality, limited liability firms will be formed. 
Cooperatives are more likely to survive in the long run if competitive pressures are relatively mild. If there are barriers to entry, established but relatively inefficient cooperatives may survive. The model suggests, however, that if one main consequence of globalization is the increase in competitive pressure, cooperatives are fated to perish. We will come back to this question in the section on globalization.

\subsection{Summary}

Contrary to the limited liability firm, the cooperative promotes trust and has a more egalitarian wage structure. In the limited liability firm, the owner keeps the residual product. Workers are generally better off in cooperatives than in limited liability firms. However, the limited liability firm is efficient and the cooperative has some slack that results in lower than efficient output. In addition, cooperatives are more likely to emerge in settings where wealth is equally spread.

In the next section we present the case study of Mondragón Corporación Cooperativa to illustrate the propositions. The case is also used to motivate our subsequent modeling and analysis of globalization.

\section{Case Study: Mondragón Corporación Cooperativa}

The case of Mondragón Corporación Cooperativa (MCC) illustrates the propositions regarding horizontal organizations made above. ${ }^{7}$ MCC is particularly interesting given the process of internationalization that the corporation has been undergoing in the past few years. We come back to the example after we extend the model to embody some of the main consequences of globalization.

MCC was a conglomerate of more than 100 industrial cooperatives with products as diverse as kitchen appliances, elevators, automobile components, sports equipment, machine tools, financial services, retail distribution, and education. The company was founded in 1956 by priest-entrepreneur Father José María Arizmendiarrieta in northern Spain's Basque Country. With 2001 sales exceeding $€ 7$ billion and a workforce of 55,000 , the corporation had grown to become the 10th largest industrial group in Spain and the largest with exclusively Spanish capital. Several of the component cooperatives were regularly awarded for their excellence in quality-management, and MCC's main research arm, Ikerlan, had collaborated in prominent R\&D ventures such as the Columbia space shuttle project for NASA.

In 1956 Arizmendiarrieta together with five former students from his Eskola Politeknikoa founded Ulgor, the first of MCC's cooperatives. Ulgor manufactured space-heating stoves and paraffin cooking appliances. The company quickly enlarged its product portfolio to include electrical products and butane-fired cookers. Accoding to one of the

\footnotetext{
${ }^{7}$ See Ramon Casadesus-Masanell and Tarun Khanna (2002) and references therein.
} 
founders: "At that time it was clear to us that any firm that could produce a useful and well-made product would succeed." In fact, the Spanish competitive environment was one of mild rivalry. Spain was an autarky and imports were for the most part forbidden and there was a significant unmet demand.

The five students decided to form Ulgor after their unsuccessful attempt to introduce worker participation in the dominant limited liability firm in town, the Unión Cerrajera, a metal working company. The necessary capital to set up Ulgor came from the founder's savings and the support of villagers. Thus, dissatisfaction with work conditions in the limited liability firm prompted the emergence of the cooperative. Of course, this is consistent with the model prediction that cooperativists achieve larger utility than workers of the limited liability firms. It is also interesting to point out that in the mid1950s wealth was reasonably equally spread in the Mondragón area. Father Arizmendiarrieta coordinated joint action in the Mondragón area and encouraged the formation of cooperatives. ${ }^{8}$

Soon after Ulgor was set up, other independent cooperatives sprung in the Mondragón area. These cooperatives established close ties among them. The cooperatives faced three main problems: access to capital and managerial expertise, exclusion from the Spanish Social Security System, and a deficient technological base. These problems triggered the creation of several new institutions. To deal with the problem of reduced access to financial resources and the lack of social security, the cooperatives created a cooperative bank, Caja Laboral Popular (CLP), and an insurance cooperative, Lagun Aro, that would offer social security services to the members of the affiliated cooperatives. CLP acted as a center for all the cooperatives adhered to the group. Soon after its creation, CLP instituted a business development division to promote new cooperatives, consolidate and coordinate the activities of the existing cooperatives, and to provide managerial expertise to troubled cooperatives. In fact, several cooperatives were born by the initiative of the CLP.The Spanish economy became much more open in the 1960s. As a consequence, 1965-1975 was a period of great expansion at Mondragón. More interesting is the fact that while in the early and mid 1990s GDP growth slowed (it became negative in 1993) and unemployment reached $23 \%$, MCC experienced larger than $14 \%$ and $4 \%$ average growth in sales and employment, respectively. The following graph shows Spain's GDP growth and MCC's sales growth trends for the periods 1970-1989 and 1990-2000. MCC's sales growth is always above that of Spain's GDP. Interestingly, MCC's sales trend is upward sloping in the 1990s, reflecting the group's internationalization efforts.

\footnotetext{
${ }^{8}$ An important precedent to MCC in the Basque Country was Alfa, Sociedad Anónima Cooperativa Mercantil y de Producción de Armas de Fuego (Cooperative Corporation for Marketing and Manufacturing Fierarms). Alfa was set up in October 28, 1920 by a group of seven workers who were dissatisfied with work conditions in limited liability firms in the metallurgy sector. After a long strike, the workers pooled their assets $(\$ 2,000$ approximately) and founded Alfa. The idea was to set up a cooperative to manufacture and market firearms with quality and prices comparable to those of limited liability firms, but where wages would be higher than those offered by limited liability firms. By 1925, however, Alfa's firearms were no longer cost-competitive. Alfa shifted operation to the manufacture of sewing machines, a less competitive industry at the time. The Alfa case shows that workers in traditional limited liability firms get less utility than what they can realize in the perhaps less efficient cooperative. The case is also consistent with the cooperative not being as efficient as the limited liability firm in low risk environments.
} 
However, Spain's GDP growth has continued the downward trend of the previous two decades.
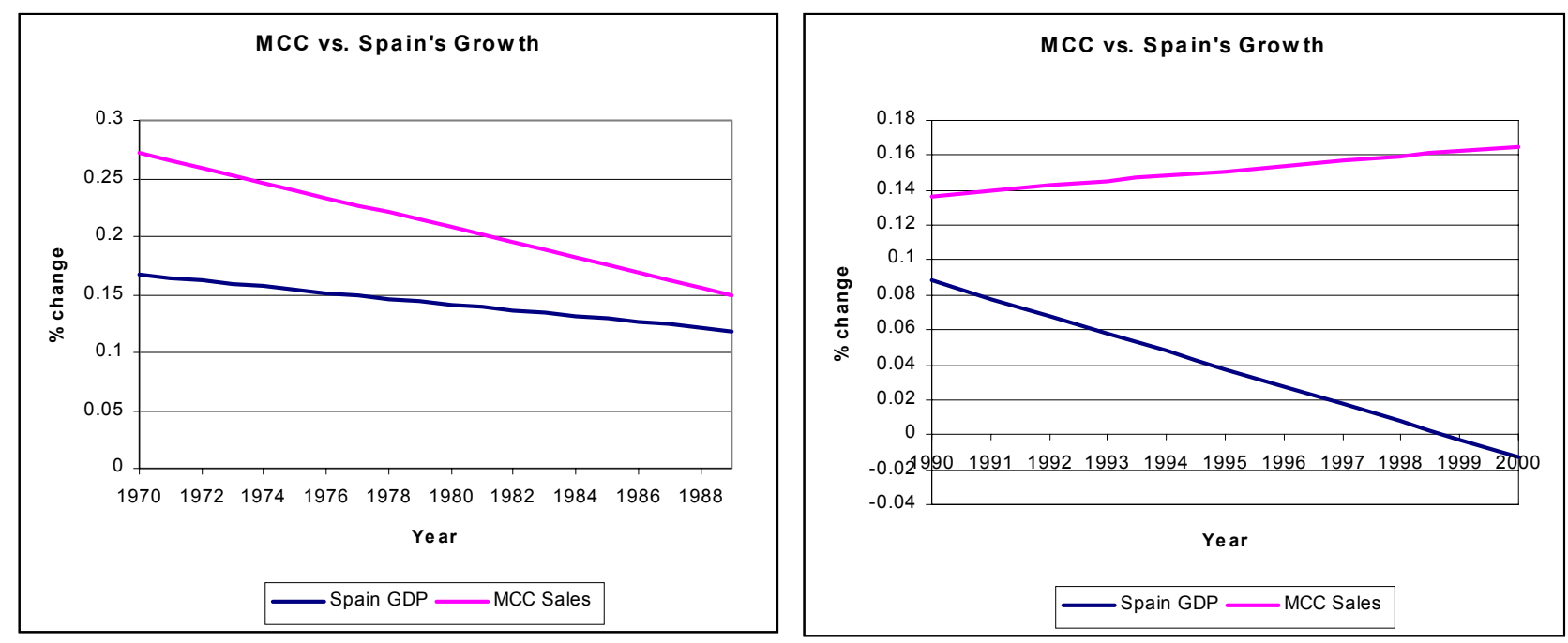

\subsection{Irizar}

We turn now to illustrating Irizar, one of the most successful cooperatives in the group Mondragón Corporación Cooperativa. Irizar's organizational structure is completely flat, with no bosses and organized through self-managed teams.

A member of MCC's Industrial Equipment division, Irizar was a manufacturer of luxury long- and medium-distance coach bodies located in Ormaiztegi, a small Gipuzkoan town close to Mondragón. The company started in 1889 as a limited liability firm that manufactured wooden carriages and stagecoaches. In 1962 Irizar became a cooperative and joined the Mondragón Cooperative Group (the predecessor of MCC). After joining Mondragón and gaining access to financial resources, Irizar extended its product line to cover the full product spectrum from luxury coaches to city buses. The company served five European countries only. Throughout the 1980s the industry became increasingly competitive and by 1991, after a sequence of false moves and misfortunes, Irizar was on the verge of bankruptcy.

As a last recourse to save the company, MCC's council named a new general manager for Irizar, Mr. Koldo Saratxaga, an executive with vast experience in managing cooperatives. Under Saratxaga's management, Irizar's progress was spectacular. While in 1991 the company had sales of $€ 18.6$ million ( $18 \%$ exports), loses of $€ 5.4$ million, 275 workers, and output of 226 coaches a year, in 2000 sales were $€ 168$ million (65\% exports in 45 countries), it employed over 600 workers in its Ormaiztegi plant alone, and it produced more than 1,400 custom-made, luxury coaches per year.

Throughout the 1990s, Irizar received several prizes for managerial excellence and product quality. The company became the first luxury coach maker to achieve ISO 9001 
and ISO 14001 certifications. Irizar was also the first Spanish company not in a multinational group to receive the European Quality Prize granted by the European Foundation for Quality Management, the most prestigious European prize to the management of quality. In 2000, Irizar was Europe's second-largest manufacturer of luxury coaches and according to 'The Economist:' "[Irizar] is probably now [year 2000] the most efficient coachbuilder in the world." 9 The Irizar case demonstrates that a cooperative may be as efficient as a limited liability firm.

\subsubsection{Trust and Teamwork at Irizar}

Mr. Saratxaga redefined the product and organizational strategies of Irizar. The new product strategy was simple: instead of offering a large product selection to a small geographic market (five countries), he proposed to specialize in one product segment, the luxury long- and medium-distance coach bodies, and to offer it to multiple geographic markets ( 45 countries by year 2000). The new strategy contained the seed of internationalization.

As fundamental as the new product strategy was the revised organizational strategy. According to Saratxaga,

Irizar is a project based on the freedom and responsibility of all its participants. Irizar knows no control or hierarchy. There is personal responsibility and the thrill to share experiences. This fosters the flow of knowledge within and between selfmanaged teams. Only those who assume the business project as their own will truly be trustworthy and motivated.

The company had no hierarchy: there were direct workers and coordinators (not directors) and strategic decisions were taken by as many people as possible. Words such as 'employee,' 'worker,' 'wage-earner' were not in Irizar's vocabulary. The absence of a formal hierarchy is a reflection of the trust in the attitude and motivation of Irizar's employees. According to Iñaki Zuloaga, mechanic:

We operate perfectly well without foremen or bosses, and responsibility is shared $100 \%$. There are really close relations between the production line and engineering, which enables objectives to be met and the customer to be satisfied. We have improved cycle times, we work more comfortably, we are better trained and we have much more initiative than before. We are much more involved with the Project and much more committed.

The team was the basic unit from which Irizar's organization was built. There were teams for all types of tasks and processes and most people belonged to several teams simultaneously. Each team had a nominated 'leader' (not to be called 'boss' or 'director') and had a great degree of autonomy; teams acted as mini, semi-independent firms. There were more than 180 teams and 140 leaders. Iñaki Alonso, a shop-floor person who was also a team leader observed:

\footnotetext{
${ }^{9}$ The Economist Intelligence Unit (2000).
} 
You don't need a supervisor, and having no intermediaries helps communication right along the line. The skills you acquire through working this way are helpful to you outside work as well. It is all about relationships and trust. It is better to use your brain, solve your own problems and to make that part of your daily routine.

Teams were reviewed at least once a year to ensure their efficiency. Mr. Saratxaga led the 'steering team.' His fellow steering team members were called 'executive coordinators.' According to Saratxaga: 'Higher level posts signify greater responsibility, or greater competency, or a wider range of coordination, but never represent authority.' Irizar had no departments. Offices and shop-floor spaces had no physical walls. According to the 1999 employee satisfaction survey, $95 \%$ of the workforce thought that the actions of their leaders merited their trust, up from 83\% in 1995.

Teams had the freedom to organize their activities as they saw most fit. This included deciding when to start and end work and how to perform the job they were supposed to do each day. There was no clocking-in and clocking-off on the shop floor. The only requirement was that where there were synchronization requirements with other teams these had to be resolved ahead of time through dialogue. According to Saratxaga,

Many people say this is a 'no rules' company. To a degree this is true. We have tried to create an environment where people spend a lot of time thinking about what needs be done to please the customer, not $80 \%$ of the time thinking how to control other people.

Work targets were agreed through democratic consensus. About $80 \%$ of Irizar's personnel contributed to the setting of annual targets.

\subsubsection{Wage Equality and Participation in Profits}

The pay scale at Irizar was amongst the flattest in MCC. Irizar's maximum post-tax pay ratio was 1:3 (highest to lowest wage). According to Saratxaga: "Because everyone likes success and power, at Irizar we all share success and power and we eliminate hierarchy."

Most of the workforce in the Ormaiztegi (Gipuzkoa) plant owned equity in the enterprise. New personnel were given a three-year probation period, and after positive evaluation by peer team members, they had the right to become full partners. Irizar's general assembly met three times a year (most other MCC's cooperatives held the general assembly once a year) and always recorded close to $100 \%$ attendance. A recent decision taken by the general assembly was to abolish supplementary payment for overtime.

Irizar paid worker-shareholders $7.5 \%$ of salary as liquid dividend. Ploughed back dividends increased steadily since 1993. 


\section{Globalization}

Globalization has three effects: an increase in market size, an increase in the strength of competition, and an increase in risk. The increase in market size results in the need to add more workers to the organization so that new demand can be met; the increase in competition means that less efficient organizations are more likely to perish; and the increase in risk places constraints on the kinds of incentive schedules that the firm is able offer.

We now investigate whether globalization bring cooperatives to an end, the likely pattern of expansion for limited liability firms and cooperatives, and whether or not globalization will result in lower levels of trust.

\subsection{Will Globalization Bring Cooperatives to an End?}

Because globalization results in higher competitive pressure, we could conclude that cooperatives are less likely to survive in a globalized world because it is a less efficient organizational form than the limited liability firm. We now show that this is not necessarily true. If the added risk brought about by globalization is large, there are circumstances in which the cooperative may do better than the limited liability firm.

\subsubsection{Risk}

We now show that if the output is random, then the cooperative may do better than the limited liability firm. If there is risk, then the limited liability firm may not be able to implement the first best outcome. Further, we show that under sufficient risk the cooperative may be more efficient than the limited liability firm.

Risk is modeled by introducing randomness on the output. After the agents have taken action vector $\left(a_{1}, a_{2}\right)$, the outcome is

$$
\tilde{y}=y+\widetilde{v}
$$

where $\widetilde{v}$ is a random variable taking values $v_{H}$ and $v_{L}\left(v_{H}>v_{L}\right)$ with probabilities $p$ and $1-p$, respectively. We let $p>\frac{1}{2}$. We assume risk neutrality and $E \widetilde{y} \geq 0$ so that it is ex ante profitable to engage in production. We say that 'risk is positive' if $E \widetilde{v} \geq 0$ and 'negative' otherwise. Positive risk refers to positive random shocks to output. Negative risk refers to negative random shocks. In what follows, we analyze the performance of the cooperative and the limited liability firm with risk. 


\subsubsection{Horizontal organization}

The analysis and results here are just as in the certainty benchmark of Section $2, \lambda_{i}>0$ and $a_{i}^{c}>\hat{a}_{i}$, there is equilibrium trust and wage equality. Because $E \tilde{y} \geq 0$ the cooperativists are willing to enter the relationship.

\subsubsection{Hierarchy}

A version of the scheme under certainty will work if workers and/or the owner has sufficient wealth. However, if the variance of $\widetilde{v}$ is large and the workers and owner are wealth-constrained, then the limited liability firm may not be able to implement the first best.

Because the random variable takes two values only, there are three outcomes of interest: $y_{H}=f\left(a_{1}^{* *}, a_{2}^{* *}\right)+v_{H}, y_{L}=f\left(a_{1}^{* *}, a_{2}^{* *}\right)+v_{L}$, and $y$ other than $y_{H}$ and $y_{L}$. The workers can make sure that either $y_{H}$ or $y_{L}$ will be realized by choosing $a_{1}^{* *}$ and $a_{2}^{* *}$. However, there are effort levels $\left(\bar{a}_{1}, \bar{a}_{2}\right)$ with $\bar{a}_{i}<a_{i}^{* *}$ such that

$$
f\left(\bar{a}_{1}, \bar{a}_{2}\right)+v_{H}=f\left(a_{1}^{* *}, a_{2}^{* *}\right)+v_{L}
$$

Thus, the agents can choose to work less than $a^{* *}$ and then attribute a low output $f\left(\bar{a}_{1}, \bar{a}_{2}\right)+\mathrm{v}_{H}$ to bad luck. Of course, if the realized output is $f\left(\bar{a}_{1}, \bar{a}_{2}\right)+\mathrm{v}_{L}$, the principal will know with certainty that the agent shirked.

The principal offers three payments $w_{H}, w_{L}$, and $\underline{w}$ corresponding to each output level. The incentive compatibility and individual rationality constraints are

$$
p w_{H}+(1-p) w_{L}-c\left(a^{* *}\right) \geq p w_{L}+(1-p) \underline{w}-c(\bar{a})
$$

and

$$
p w_{H}+(1-p) w_{L}-c\left(a^{* *}\right) \geq 0
$$

Finally, the principal minimizes the expected payment

$$
\min _{\left\{w_{H}, w_{L}, \underline{w}\right\}} p w_{H}+(1-p) w_{L}
$$

Observe first that the principal would like to set $\underline{w}$ as low as possible because outputs associated with $\underline{w}$ are never desirable. In fact, if the agents are not wealth-constrained, the principal would choose $w_{H}$ and $w_{L}$ so that $p w_{H}+(1-p) w_{L}=c\left(a^{* *}\right)$ and $\underline{w}$ low enough so that the incentive compatibility constraint is satisfied. Such constraint has the 
minimum possible expected cost to the principal and implements $a^{* *}$. The workers are left with zero expected utility.

However, if the agents are wealth-constrained then the smallest possible value of $\underline{w}$ is 0 . In this case, if the principal is not wealth-constrained, he can set $\underline{w}=w_{L}=0$ and $w_{H}$ large enough so that the participation constraints are satisfied. This contract will again induce the agents to choose the first best efforts. The expected cost to the principal is the same as in the contract with low w; the workers are left with zero expected utility. To summarize,

Proposition 7 Without budget constraints (firm and/or workers), the limited liability firm is able to implement the first best action at the lowest possible cost.

Notice also that trust will not emerge here. In equilibrium we have that $a=a^{* *}$ and thus the pressure function is zero. Therefore, there is no value to setting $\lambda>0$. Finally, wages (in expected terms) are unequal: the workers get zero expected utility whereas the principal makes a strictly positive amount of money.

If the firm or workers do not have unlimited wealth, the budget constraints are

$$
w_{H} \geq 0 \quad w_{L} \geq 0 \quad \text { and } \quad \underline{w} \geq 0
$$

and

$$
w_{H} \leq f\left(a_{1}^{* *}, a_{2}^{* *}\right)+v_{H} \quad w_{L} \leq f\left(a_{1}^{* *}, a_{2}^{* *}\right)+v_{L} \quad \text { and } \quad \underline{w} \leq f\left(\bar{a}_{1}, \bar{a}_{2}\right)+v_{L}
$$

It is easy to see that in this case the feasible set may be empty. Thus, there may be no contract that resutls in the workers choosing $\left(a_{1}^{* *}, a_{2}^{* *}\right)$. See graph 1 . The factors that favor the implementability of $\left(a_{1}^{* *}, a_{2}^{* *}\right)$ are:

- Large expected value of $\tilde{y}$. In this case the budget constraints are less likely to be binding. In particular, if $v_{H}$ is sufficiently large, then $\left(a_{1}^{* *}, a_{2}^{* *}\right)$ is implementable.

- $\quad p$ close to 1 . When $p$ is close to 1 , the variance of output $\left(p(1-p)\left(v_{H}-v_{L}\right)^{2}\right)$ is small and the information problem is less severe.

- Small difference between $c\left(a^{* *}\right)$ and $c(\bar{a})$. When $c\left(a^{* *}\right)$ is close to $c(\bar{a})$, the incentives problem is less severe and thus it is easier to implement $\left(a_{1}^{* *}, a_{2}^{* *}\right)$.

- Large difference between $y^{* *}$ and $c\left(a^{* *}\right)$. In this case the budget constraint is less likely to be binding. 
Suppose that the workers cannot be induced to choose $\left(a_{1}^{* *}, a_{2}^{* *}\right)$, what can the limited liability firm implement? If the incentives problem is sufficiently severe, ${ }^{10}$ the only implementable efforts through the scheme presented above are $\left(\bar{a}_{1}, \bar{a}_{2}\right)$.

If the 'forcing' contract is not a possibility, the principal can always offer a commission contract by which the agents get $\alpha_{1} y$ and $\alpha_{2} y$ and the principal keeps $\left(1-\alpha_{1}-\alpha_{2}\right) y$. In this case, the agents will develop some trust (but less than in the cooperative because $\alpha_{i}<\frac{1}{2}$ ) and the limited liability firm will do worse than the cooperative. Thus,

Proposition 8 With risk and wealth constraints, the cooperative may do better than the limited liability firm.

The limited liability firm provides incentives to work through monetary compensation only. The structure of the optimal compensation contracts in the limited liability firm does not promote the emergence of trust and intrinsic motivation. The lack of intrinsic incentives is not problematic under of certainty because compensation schemes can be tailored exactly so that the ex post available financial resources will be sufficient to honor such contracts. Proposition 8 shows that compensation schemes for limited liability firms that lead to first best outcomes are not robust to the introduction of risk. Risk makes it impossible to know with certainty what the available financial resources will be ex post, and thus the set of feasible ex ante contracts is substantially reduced. When the constraints on the ex ante contracts brought about by risk are sufficiently severe, the limited liability firm may be better off offering profit-sharing contract similar to that granted by cooperatives. The cooperative is far less affected by risk. Profit sharing is a far more robust contract. Trust will emerge regardless of the presence or absence of risk.

We conclude that globalization does not imply that the cooperative will be brought to an end. Although the competitive environment becomes tougher with globalization, the increased risk may hamper the ability of the limited liability firm to implement actions above those that the cooperativists will undertake.

The case of Irizar illustrates the theoretical arguments we just presented. In 2001, Irizar was the most international cooperative in MCC, measured by international sales and countries where it commercialized its products. Irizar had plants in Brazil (1998), China (1995), India (2001), Mexico (1999), and Morocco (1998) and it was commercially active in 65 countries. The countries chosen reflected market opportunities as well as the cost of labor, an important input in coach body manufacturing (as opposed to the highly automated automobile body production). Brazil was the world's largest luxury-coach market and India and China both had great potential. International plants were run by executives that had been promoted from inside Irizar.

${ }^{10}$ This depends on $f, c$, and parameters $p, \mathrm{v}_{H}$ and $\mathrm{v}_{L}$. 
As Irizar expanded globally, not only its profitability grew dramatically (see Table 1) but the company was also awarded several prizes for quality management, including the top annual prize granted by the European Foundation for Quality Management.

Table 1: Irizar's performance

\begin{tabular}{rrrrrrrr} 
& \multicolumn{2}{c}{ Sales } & \multicolumn{2}{c}{$\begin{array}{c}\text { Internat. } \\
\text { Sales }\end{array}$} & $\begin{array}{c}\text { Add. Value/ } \\
\text { worker }\end{array}$ & Workforce & Return on \\
Sales & Return on & Assets & Equity \\
& Million $€$ & \multicolumn{1}{c}{$\begin{array}{c}\text { Million } € \\
\text { Thousand } €\end{array}$} & \multicolumn{2}{c}{$\begin{array}{c}\text { \% } \\
\%\end{array}$} & Million $€$ \\
\hline 1991 & 18.6 & 3.2 & 16.8 & 225 & n.a. & n.a. & 1.8 \\
1992 & 23.5 & 4.6 & 31.3 & 290 & n.a. & n.a. & 4.8 \\
1993 & 25.9 & 17.5 & 32.5 & 280 & 7.5 & 12 & 6.0 \\
1994 & 41.0 & 25.2 & 39.1 & 403 & 11 & 24 & 10.8 \\
1995 & 56.4 & 28.8 & 54.7 & 515 & 16 & 34 & 19.8 \\
1996 & 60.6 & 31.7 & 55.9 & 580 & 18 & 35 & 26.4 \\
1997 & 64.4 & 25.5 & 54.1 & 570 & 19 & 37 & 38.5 \\
1998 & 99.2 & 55.1 & 67.0 & 675 & 20 & 39 & 58.9 \\
1999 & 124.1 & 76.0 & 75.0 & 796 & 21 & 41 & 80.5 \\
2000 & 153.2 & 110.9 & 87.6 & 843 & n.a. & n.a. & n.a. \\
\hline
\end{tabular}

Source: Irizar internal documents

Finally, as Irizar increased its global presence, democratic practices and wage equality in the Ormaiztegi plant have persevered.

\subsection{Mode of Expansion}

We now turn to the question of how are the cooperative and the limited liability firms likely to expand to meet the increase on demand brought about by globalization. To begin, we assume that there is no increase in risk and that there are plenty of potential workers in the international markets with no assets. We distinguish two cases: separable and non-separable production technologies.

Suppose that technology is separable. By this we mean that a second organization can be set up that is completely independent from the original cooperative or limited liability firm. In this case, the cooperative and the limited liability firm will both expand by setting up multiple parallel operations in the form of limited liability firms. The cooperative will set up limited liability firms around the world. The reason is that the limited liability firm is more efficient and makes more money for the owner of the assets, regardless of whether it is a limited liability firm or a cooperative. However, if there is an increase in risk associated to globalization, the additional productive units may be set up as cooperatives, not limited liability firms.

Now assume that the technology is not separable. The limited liability firm will pay the additional workers the cost of their effort and demand from them the first best level of effort. The cooperative cannot do this. The reason is that with this arrangement the 
cooperativists have an incentive to shirk (just a little) so that the additional workers end up getting the minimum possible wage. The new workers, anticipating this, decide no to join the cooperative. Thus, in the case of non-separability, a hybrid organization is not possible and the cooperative expands as a cooperative. The expanded cooperative will typically set $\alpha$ for the members of the original firm substantially larger than to the new members.

Will new cooperatives appear? This is unlikely if the cooperatives and limited liability firms from the developed country are wealth unconstrained. The workers in the undeveloped countries will have little incentive to set up cooperatives: either they have the money to set up a limited liability firm or they are better off working for somebody else.

\section{The Internationalization of MCC}

One of the basic objectives for all of MCC's cooperatives for 2000-2004 was internationalization. Mr Cancelo explained:

The traditional scheme worked well while business was simple: a few products, stable customers in a well-defined geographic area, and a well-understood and almost invariable competitive landscape. However, the world has changed: new, larger competitors are now fighting for a share of the local market. New, better products are introduced at a faster pace. New customers and suppliers crop up from countries that a few years ago we would have never even thought about. Guidance is not to be found in history; invariably, repetition of old strategies leads to failure.

Mr. Jesús Ma Herrasti, MCC's director for international operations, mentioned the following reasons for the internationalization of $\mathrm{MCC}$ :

First, our clients are increasingly global and, thus, if we want to satisfy their demands we have to enhance our international presence. Second, in the last few years we have seen a reorganization of international capital markets leading to greater efficiency and access. As a consequence, there are new business opportunities in diverse geographic areas that we should not let pass. Third, to stay competitive MCC's cooperatives need to locate certain activities where factor costs are low. For the most part, value-added activities will remain in the Basque Country but a number of labor-intense activities will be undertaken in other more advantageous geographic locations. Finally, we cannot close our eyes to the new international context: media, entertainment, finances, and all kinds of businesses are becoming increasingly global. As technology improves, physical distances become smaller and the information and knowledge that we have of each other is dramatically increased.

MCC set up an international network of commercial offices to assist the cooperatives in their international development. Countries were chosen according to their market 
potential and economic and political complexity. In 2001, MCC had commercial offices in USA, Mexico, Brazil, Iran, India, and China. In addition, cooperatives wishing to expand internationally had access to low interest loans (fondos intercooperativos) provided by MCC. Also, cooperatives shared their international experiences with one another.

Some thought that that globalization was fundamentally against MCC's original goal of creating employment in the Basque Country. But, according to Mr. Cancelo: "The only way to ensure MCC's survival in the Basque Country is by being present in the rest of the world. This is a must." In addition, there was a lively debate within MCC on whether the globalization model adopted by the vast majority of cooperatives where foreign workers were not shareholder-partners was consistent with the original basic principles of the Mondragón cooperative experience. Mr. Herrasti concurred:

Our forecast is that by 2004, one fourth of the Industrial Group's workforce will be in international plants. If we do not act fast in incorporating these workers to our cooperative model we run the risk of winding up with a select nucleus of privileged shareholder-partners in the Basque Country and tens of thousands of wage-earners abroad. When we began our globalization process back in 1996, our main priority was to consolidate our international presence fast. As we achieve this objective, we need to reflect on how to implement a management model close, if not identical, to the Mondragón cooperative benchmark. We are known internationally for the success of our cooperative experience. We now face the challenge to also being recognized for having implemented a globalization paradigm coherent with our cooperative principles and values.

\subsection{Irizar's International Strategy}

As a consequence of Irizar's product strategy under Saratxaga, the company pursued international expansion aggressively. All of Irizar's international plants were limited liability companies, not cooperatives. Among other reasons, directors cited the difficulty of exporting the cooperative model to countries lacking a tradition of democratic organization: "It is very hard for people in some of the target countries to grasp the concept of cooperativism where workers are owners and where decisions are made through mechanisms resembling democratic political institutions." In addition, some of the countries had no law of cooperatives and, thus, cooperatives could not legally be constituted. Moreover, because equity joint venture was the main mode of internationalization and essentially all partners were limited liability companies, the natural legal form for the joint venture was that of a limited liability company.

Finding individuals willing to leave the Basque Country was a challenge for most cooperatives in the MCC system and Irizar was not different. As a compromise, nearly all cooperatives sent executives overseas for a limited period of time, usually three years. For example, in July of 1998 Mr. Fabián Berridi from Irizar was sent to Botucatu, Brazil, 
to open the first Irizar plant in the American continent. Talking about his experience, $\mathrm{Mr}$. Berridi observed:

From the moment in which Irizar committed to a global strategy we all knew that someone would have to assume these kind of responsibilities. Among all of us at Irizar, a few people were more likely to be asked to lead this effort -- because of professional experience, age, family obligations, and what was expected from them. I was thrilled to have been given the opportunity to confront this challenge. However, with the exception of the professional dimension, I miss everything else from the Basque Country.

\section{Ruminations on Limitations and Alternative Explanations}

Selection stories - articulating what kinds of circumstances are conducive to employees getting together to form cooperatives - have appropriately received some theoretical attention, most notably in Miyazaki (1984). However, this model is inconsistent with the Mondragon evidence. It predicts that cooperatives will form when prospects for the firm are dubious. Here, however, Irizar took on more of the characteristics of a cooperative (greater wage equality, most notably) at a time of expansion and did so profitably. Further, as its prospects have brightened, it has not turned away from being a cooperative - indeed, it is the poster child of success. It is perhaps worth noting that there are lots of examples around the world of cooperatives that have thrived amidst global cooperation Amul, the dairy cooperative in India; Felda the plantation cooperative in Malaysia, and the rising number of cooperatives in Finland.

But perhaps a more general selection story is at work here - having to do with the structure of outside opportunities in the Basque country and the motivation for talent to remain at Mondragon. It is true that Mondragon did particularly well when outside opportunities contracted in Spain in the 1990s. This is consistent with Mondragon perhaps retaining talent more easily during this time. But the period of opening up of Spain to the world in the 1960s was also a time when outside opportunities in Spain expanded and Mondragon did well. A pure selection story would have trouble reconciling itself with both these explanations.

Further, our field interviews clarify two things. First, that there are strong emotional and nationalism-related reasons (support of Basque 'nation') why talent stays at Mondragon, suggesting that the economic selection effect is probably weakened and unlikely to provide the sole compelling explanation. Second, and consistent with this, we encountered quite a few senior managers who had relocated to the Basque country from more lucratic employment in well-known multinationals elsewhere in Spain and around the world, again casting doubt on the selection story.

One could argue that this solidarity causes preferences among Basques to be reasonably well-aligned and, as Hart and Moore (1998) show, this alignment promotes the efficiency of cooperatives. But note that, in their model, such preference alignment among 
cooperative members is exogenous - our focus is on modeling when cooperation - a plausible correlate of solidarity - arises. Further, a pure nationalism story or 'love of Basque culture/language' story would not be able to explain time-series variation in the performance of Irizar and therefore would be ill-equipped to account for the effect of globalization on cooperatives and trust.

One could also argue that Mondragon did well not because it was a cooperative but because it began to move away from its cooperative structure during the time of globalization. Proponents of this view would point in particular to the greater incidence of non-member workers at Mondragon in recent years. This is precisely the implication of the Miyazaki (1984) model - that successful cooperatives will begin to dismantle themselves. But it is not what seems to be going on at Irizar. And it is emphatically not the tone taken by Mondragon members - they see the arrival of outsider workers not as a plus of the evolution of their business model, but as a serious challenge to Mondragon's viability.

Finally is it the case that trust causes globalization (see Grief (1994), Kotkin (1993), Landa (1995), Rauch and Trinidade (2002)) at Mondragon, rather than globalization causing trust? If this were the case, Mondragon would very much be organized as a cooperative in other countries, but it is not. The signature features of cross border diaspora networks emphasized by Greif for instance are not seen in Mondragon's internationalization. We conclude that the likely causation behind our observed correlation indeed is from globalization inducing trust, and thereby greater performance. 


\section{References}

George Akerlof, "The Market for Lemons: Quality Uncertainty and the Market Mechanism," 84 Quarterly Journal of Economics 488, 1970.

Nabil Al-Najjar and Ramon Casadesus-Masanell, "Trust and Discretion in Agency Contracts," Mimeo, Harvard Business School, 2002.

Kenneth Arrow, "The Economics of Moral Hazard: Further Comment," 58 American Economic Review (Communications) 537, 1968.

Kenneth J. Arrow, "Gifts and Exchanges," 1 Philosophy and Public Affairs 357, Summer 1972.

Kenneth Arrow, The Limits of Organization, New York: Norton, 1974.

John P. Bonin, Derek C. Jones, and Louis Putterman, "Theoretical and Empirical Studies of Producer Cooperatives: Will Ever the Twain Meet?" 31(3) Journal of Economic Literature 1290-1320, 1993.

Ramon Casadesus-Masanell and Tarun Khanna, "Mondragón Corporación Cooperativa," Harvard Business School case N9-702-457, 2002.

Ramon Casadesus-Masanell and Daniel F. Spulber, “Agency Revisited,” Mimeo, Harvard Business School, 2002.

Amy Chua, World on Fire: How Exporting Free Market Democracy Breeds Ethnic Hatred and Global Instability, Doubleday, $1^{\text {st }}$ Ed., 2002.

James S. Coleman, Foundations of Social Theory, Cambridge, MA: The Belknap Press of Harvard University Press, 1990.

Richard Craswell, "On the Uses of 'Trust': Comment on Williamson, 'Calculativeness, Trust, and Economic Organization'," 36 Journal of Law and Economics 487-500, 1993.

Economist Intelligence Unit, “The Global Bus and Coach Industry: Fortunes Revive,” in EIU Motor Business International, 1st Quarter, 2000.

John King Fairbank, The Great Chinese Revolution - 1800-1985, Chapter 6: The Western Intrusion, Harper Perennial, 1987.

Robert Feenstra, "Integration of Trade and Disintegration of Production in the Global Economy", The Journal of Economic Perspectives, Vol. 12, No. 4., pp. 31-50, Autumn, 1998. 
Raymond Fisman and Khanna, Tarun, "Is Trust a Historical Residue? Information Flows and Trust Levels," Journal of Economic Behavior and Organization, Volume 38, pp. 79-92, January 1999.R. H. Frank, "If Homo Economicus Could Choose His Own Utility Function, Would He Want One With a Conscience?" 77 American Economic Review 593, 1987.

Francis Fukuyama, Trust: The Social Virtues and the Creation of Prosperity, New York: The Free Press, 1995.

Diego Gambetta (editor), Trust: Making and Breaking Cooperative Relations, New York: B. Blackwell, 1988.

Pankaj Ghemawat and Khanna, Tarun, "The Nature of Diversified Business Groups: A Research Design and Two Case Studies," Journal of Industrial Economics, Volume XLVI, No. 1, pp. 35-62, March 1998.

Mark Granovetter, "Coase Encounters and Formal Models: Taking Gibbons Seriously," 44 Administrative Science Quarterly 158, 1999.

Avner Greif, "Cultural Beliefs and the Organization of Society: A Historical and Theoretical Reflection on Collectivist and Individualist Societies," Journal of Political Economy, Vol. 102 (5). p 912-50. October 1994.

Luigi Guiso, Sapienza, Paula \& Zingales, Luigi, "The Role of Social Capital in Financial Development," University of Chicago GSB and Kellogg Graduate School of Management Working Paper, 2002.

H. Hansmann, The Ownership of the Enterprise, Cambridge, MA: Harvard University Press, 1996.

Oliver Hart and John Moore, “Cooperatives vs. Outside Ownership,” NBER Working Paper 6421, 1998.

Bengt Holmstrom, "Moral Hazard in Teams," Bell Journal of Economics 13(2), pp. 32440, 1982.

Tarun Khanna and Palepu, Krishna, "Policy Shocks, Market Intermediaries and Corporate Strategy: Evidence from Chile and India," Journal of Economics and Management Strategy, Vol. 8, No. 2, pp. 271-310, 1999.

Stephen Knack and Philip Keefer, "Does Social Capital Have an Economic Payoff? A Cross-Country Investigation,” Quarterly Journal of Economics, 1997, 1251- 1288.

Joel Kotkin, Tribes: How Race, Religion, and Identity Determine Success in the New Global Economy, New York, Random House, 1993. 
Janet Landa, Trust, Ethnicity, and Identity: Beyond the New Institutional Economics of Ethnic Trading Networks, Contract Law, and Gift-Exchange, Ann Arbor, MI: University of Michigan Press, 1995.

Rafael La Porta, Rafael, Lopez-de-Silanes, Florencio, Shleifer, Andrei, and Vishny, Robert, "Trust in Large Organizations," American Economic Review Papers and Proceedings, Vol. 87, No. 2, pp. 333-338, 1999.

Dalia Marin and Verdier, Thierry, "Globalization and the 'New Enterprise'," University of Munich and DELTA Working Paper, 2002.

Hajime Miyazaki, "On Success and Dissolution of the Labor-managed Firm in the Capitalist Economy," 92(5) The Journal of Political Economy 909-931, 1984.

Mahathir Mohamad, A New Deal for Asia, Pelanduk Pubns. Sdn. Bhd., $1^{\text {st }}$ Ed., 2000.

Matthew Rabin, "Incorporating Fairness into Game Theory and Economics," 83 American Economic Review 1281, 1993.

W. Raub, "A General Game-Theoretic Model of Preference Adaptations in Problematic Social Situations," 2 Rationality and Society 67, 1990.

James Rauch and Vitor Trindade (1999), "Ethnic Chinese Networks in International Trade", Review of Economics and Statistics, 2002.

Dani Rodrik, Has Globalization Gone Too Far?, Institute for International Economics, Washington D.C., March 1997.

Julio Rotemberg, "Human Relations in the Workplace," 102 Journal of Political Economy 684, 1994.

Kevin O'Rourke and Williamson, Jeffrey, Globalization and History: The Evolution of a Nineteenth-Century Atlantic Economy, MIT Press, 1999.

Jeffrey Sachs and Warner, Andrew "Economic reform and the process of the process of global integration," Brookings Papers on Economic Activity, 25th Anniversary Issue, 1995.

Adam Smith, The Theory of Moral Sentiments, 1759, published by Amerst, New York: Prometheus Books, 2000.

Joseph Stiglitz, Globalization and its Discontents, W.W. Norton \& Co., 2002.

Alan Taylor and Maurice Obstfeld, Global Capital Markets : Integration, Crisis, and Growth, Cambridge University Press, Forthcoming, October 2003. 
Benjamin Ward, "The Firm in Illyria: Market Syndicalism," 48(4) American Economic Review 566-589, 1958.

Oliver E. Williamson, "Calculativeness, Trust, and Economic Organization,” 36 Journal of Law and Economics 453, 1993. 


\section{WILLIAM DAVIDSON INSTITUTE WORKING PAPER SERIES}

The Working Paper Series may be downloaded free of charge at: www.wdi.bus.umich.edu

CURRENT AS OF 10/14/03

\begin{tabular}{|c|c|c|}
\hline Publication & Authors & Date \\
\hline $\begin{array}{l}\text { No. 592: Globalization and Trust: Theory and Evidence from } \\
\text { Cooperatives }\end{array}$ & $\begin{array}{l}\text { Ramon Casadesus-Masanell and } \\
\text { Tarun Khanna }\end{array}$ & June 2003 \\
\hline $\begin{array}{l}\text { No. 591: Restructuring or Disintegration of the German Corporate } \\
\text { Network: Globalization as a Fifth Column }\end{array}$ & Bruce Kogut and Gordon Walker & June 2003 \\
\hline $\begin{array}{l}\text { No. 590: Institutional Change and Firm Creation in East-Central } \\
\text { Europe: An Embedded Politics Approach }\end{array}$ & Gerald A. McDermott & June 2003 \\
\hline $\begin{array}{l}\text { No. 589: Legitimacy, Interest Group Pressure and Institutional Change: } \\
\text { The Case of Foreign Investment and Host Country Governments }\end{array}$ & $\begin{array}{l}\text { Witold J. Henisz and Bennet A. } \\
\text { Zelner }\end{array}$ & June 2003 \\
\hline $\begin{array}{l}\text { No. 588: Institutions and the Vicious Circle of Distrust in the Russian } \\
\text { Household Deposit Market, 1992-1999 }\end{array}$ & Andrew Spicer and William Pyle & June 2003 \\
\hline $\begin{array}{l}\text { No. 587: Foreign Direct Investment and the Business Environment in } \\
\text { Developing Countries: the Impact of Bilateral Investment Treaties }\end{array}$ & $\begin{array}{l}\text { Jennifer Tobin and Susan Rose- } \\
\text { Ackerman }\end{array}$ & June 2003 \\
\hline No. 586: Trust in China: A Cross-Regional Analysis & Rongzhu Ke and Weiying Zhang & June 2003 \\
\hline No. 585: Family Control and the Rent-Seeking Society & $\begin{array}{l}\text { Randall Morck and Bernard } \\
\text { Yeung }\end{array}$ & June 2003 \\
\hline $\begin{array}{l}\text { No. 584: Wage Determination: Privatised, New Private and State } \\
\text { Owned Companies, Empirical Evidence from Panel Data }\end{array}$ & $\begin{array}{l}\text { Tomasz Mickiewicz and Kate } \\
\text { Bishop }\end{array}$ & June 2003 \\
\hline No. 583: An Investigation of Firm-Level R\&D Capabilities in East Asia & $\begin{array}{l}\text { Gary H. Jefferson and Zhong } \\
\text { Kaifeng }\end{array}$ & June 2003 \\
\hline $\begin{array}{l}\text { No. 582: R\&D and Technology Transfer: Firm Level Evidence From } \\
\text { Chinese Industry }\end{array}$ & $\begin{array}{l}\text { Albert G.Z. Hu, Gary H. } \\
\text { Jefferson, Guan Xiaojing and } \\
\text { Qian Jinchang }\end{array}$ & June 2003 \\
\hline $\begin{array}{l}\text { No. 581: Credit Market Disequilibrium in Poland: Can We Find } \\
\text { What We Expect? Non-Stationarity and the "Min" } \\
\text { Condition }\end{array}$ & $\begin{array}{l}\text { Christophe Hurlin†and Rafal } \\
\text { Kierzenkowski }\end{array}$ & June 2003 \\
\hline $\begin{array}{l}\text { No. 580: Does it Take a Lula to go to Davos? } \\
\text { A Brief Overview of Brazilian Reforms, } 1980-2000\end{array}$ & $\begin{array}{l}\text { Nauro F. Campos, Armando } \\
\text { Castellar Pinheiro, Fabio } \\
\text { Giambiagi and Maurício M. } \\
\text { Moreira }\end{array}$ & June 2003 \\
\hline $\begin{array}{l}\text { No. 579: Ceaseless Toil? Health and Labor Supply of the Elderly in } \\
\text { Rural China }\end{array}$ & $\begin{array}{l}\text { Dwayne Benjamin, Loren Brandt } \\
\text { and Jia-Zhueng Fan }\end{array}$ & June 2003 \\
\hline $\begin{array}{l}\text { No. 578: Shadow Economy, Rent-Seeking Activities and the Perils of } \\
\text { Reinforcement of the Rule of Law }\end{array}$ & Ekaterina Vostroknutova & June 2003 \\
\hline $\begin{array}{l}\text { No. 577: No Pain, No Gain: Market Reform, Unemployment, and } \\
\text { Politics in Bulgaria }\end{array}$ & Neven Valev & June 2003 \\
\hline $\begin{array}{l}\text { No. 576: Power Analysis of the Nice Treaty On the Future of European } \\
\text { Integration }\end{array}$ & Yener Kandogan & June 2003 \\
\hline $\begin{array}{l}\text { No. 575: Democracy's Spread: Elections and Sovereign Debt in } \\
\text { Developing Countries }\end{array}$ & $\begin{array}{l}\text { Steven A. Block, Burkhard N. } \\
\text { Schrage, and Paul M. Vaaler }\end{array}$ & June 2003 \\
\hline $\begin{array}{l}\text { No. 574: Reintroducing Intergenerational Equilibrium: Key Concepts } \\
\text { Behind the New Polish Pension System }\end{array}$ & Marek Góra & June 2003 \\
\hline $\begin{array}{l}\text { No. 573: Why Does FDI Go Where It Goes? New Evidence From the } \\
\text { Transition Economies }\end{array}$ & $\begin{array}{l}\text { Yuko Kinoshita and Nauro F. } \\
\text { Campos }\end{array}$ & June 2003 \\
\hline $\begin{array}{l}\text { No. 572: Private Savings in Transition Economies: Are There Terms of } \\
\text { Trade Shocks? }\end{array}$ & Abdur R. Chowdhury & May 2003 \\
\hline $\begin{array}{l}\text { No. 571: On the long-run determinants of real exchange rates for } \\
\text { developing countries: Evidence from Africa, Latin America and Asia }\end{array}$ & Imed Drine and Christophe Rault & May 2003 \\
\hline $\begin{array}{l}\text { No. 570: A re-examination of the Purchasing Power Parity using non- } \\
\text { stationary dynamic panel methods: a comparative approach for } \\
\text { developing and developed countries }\end{array}$ & Imed Drine and Christophe Rault & May 2003 \\
\hline
\end{tabular}

